\title{
PROBLEEMAREAS BY DIE GEBRUIK VAN DIESELFDE OF AFSONDERLIKE TOETSE VIR VERSKILLENDE BEVOLKINGSGROEPE IN DIE BEROEPSLEWE
}

\author{
I. VAN W. RAUBENHEIMER* \\ DEPARTEMENT BEDRYFSIELKUNDE \\ RANDSE AFRIKAANSE UNIVERSITEIT
}

\begin{abstract}
Problem areas associated with using similar and different mental tests on different population groups for predicting occupational success are discussed. Suggestions for future research are made.
\end{abstract}

'n Land se onderwys- en opvoedingstelsel speel 'n belangrike rol in die voorbereiding van sy landsburgers vir die beroeps- en gemeenskapslewe. In hierdie voorbereidingsproses neem sielkundige meting 'n vername plek in. Vanaf die bepaling van skoolgereedheid tot die uiteindelike keuring vir 'n bepaalde beroep, kry 'n individu periodiek met sielkundige meting te doen. Die grootste gedeelte van hierdie meting het te make met die voorspelling van prestasie of sukses hetsy op skool, kollege of universiteit, óf in 'n beroep.

Heelwat navorsing oor baie jare toon aan dat vermoënstoetse die konstantste en sterkste voorspeller van prestasie is. Meeste studies dui daarop dat die korrelasie tussen vermoë en prestasie in die omgewing van 0,50 tot 0,65 lê (Chissom \& Lanier 1975; Lavin, 1965).

Weliswaar dra persoonlikheids- en motiveringsfaktore ook by tot die voorspelling van prestasie - hoewel die verband heelwat laer is (ongeveer 0,30). In die lig hiervan is dit dan ook goed te begryp dat vermoënsmeting en meer bepaald verstandsmeting oor die jare heen die meeste aandag van navorsers geniet het. Cattell (1971) is nietemin van oordeel dat indien al drie groepe van faktore saam geneem word as basis van voorspelling, en die meetinstrumente voldoen aan die normale funksionele vereistes, dit die voorspelbaarheid van prestasie aansienlik kan verbeter.

\footnotetext{
* Versoeke vir afdrukke moet aan die skrywer gerig word
} 
Gegewe 'n tyd- en ruimtebeperking word in die volgende gedeeltes egter oorwegend aandag geskenk aan die meting van verstandelike vermoë en sekere probleme wat daarmee gepaard gaan.

\section{DIE VERSKIL IN VERSPREIDINGS VAN TOETSRESULTATE VAN VERSKILLENDE BEVOLKINGSGROEPE}

Die sentrale tema van hierdie artikel kan gekoppel word aan die verskynsel dat daar verskille bestaan tussen verspreidings van sielkundige (en meer bepaald verstands-) toetsresultate van verskillende bevolkingsgroepe. Daar is vandag geen twyfel meer oor die bestaan van hierdie verskille en oor die statistiese beduidendheid daarvan nie.

Verskeie navorsingstudies (meeste in die VSA uitgevoer) oor die afgelope sewe dekades of meer het aan die lig gebring dat die gemiddelde verstandstoetstelling van Swart mense tussen 10 en 20 I.K.-punte laer is as dié van Blankes en dat minder as $25 \%$ Swartes gewoonlik hoër as die mediaantelling van Blankes presteer (Vergelyk Shuey, 1966).

Baughman en Dahlstrom (1968) vat die tipiese bevindinge oor hierdie aangeleentheid in die volgende figuur saam:

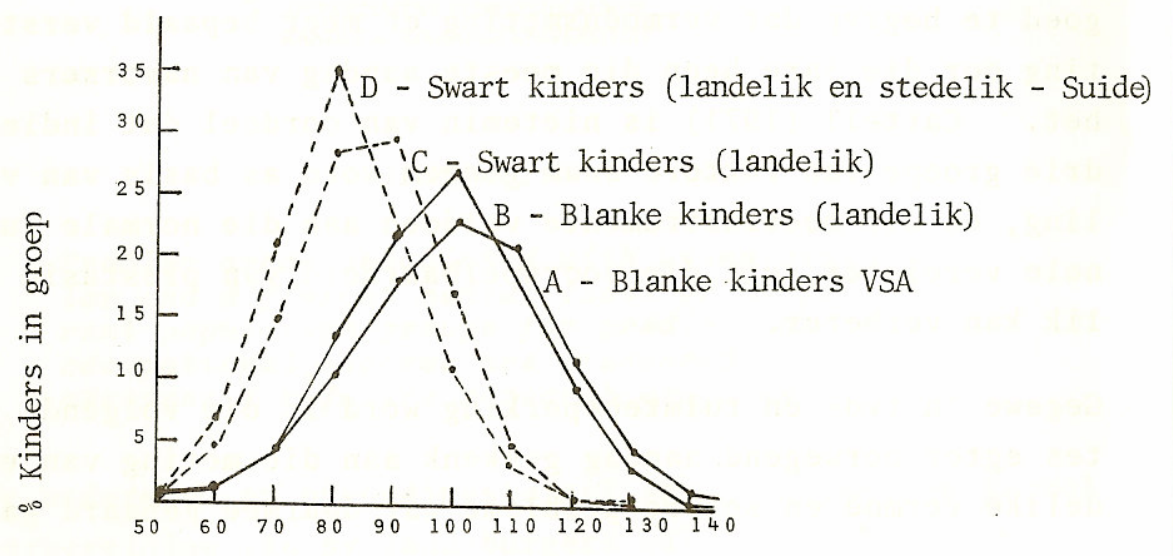

Middelpunt van I.K.-intervalle

Figuur 1 : Persentasie kinders van 4 navorsingsgroepe met verskillende I.K.-tellings

Wanneer daar van bevolkingsverskille ten opsigte van enige eienskap gepraat word moet die onderskeid tussen individu en groep steeds in gedagte gehou word. Die verskille in 
intelligensie waaroor dit hier gaan is gemiddelde verskille tussen groepe. Dat individuele tellings ver kan, en wel afwyk van gemiddelde tellings en dat daar aansienlike oorvleueling tussen die verspreidings van I.K.-tellings tussen verskillende bevolkingsgroepe is, is 'n welbekende en goed gedokumenteerde feit. In hierdie verband verwys Jensen (1969, p. 63) na die begrip van reaksieomvang (reaction range) wat sy oorsprong in die Genetika het. Dit kom daarop neer dat individue uit dieselfde genepoel verskillend kan reageer op dieselfde omgewingstoestande. Dieselfde genotipes mag dus in verskillende fenotipes ontwikkel afhangende van die gunstigheid van die omgewing en die bepaalde eienskap ter sprake.

Die verskil in verstandstoetsresultate tussen verskillende bevolkingsgroepe as sodanig, is deur wetenskaplikes erken en aanvaar en navorsing op hierdie terrein het vir jare sy normale rustige gang gegaan. Eers toe die sosiale-, maatskaplike-, beroeps- en politieke implikasies daarvan besef is (daaroor later meer), is dit uit die arena van die wetenskapswêreld getrek en is elke faset daarvan deur die openbare mening gefynkam. In hierdie proses het die regspleging ook 'n belangrike rol vertolk - soos later duideliker sal blyk.

Hoewel aanvanklik ietwat gesteurd deur die openbare konsumpsie van, en in sekere gevalle kritiek op, die inligting en kennis wat deur moeitevolle navorsing genereer is, het die nuwe verloop van sake vir die sielkundige of gedragswetenskaplike 'n onskatbare bron van stimulering gebied. Dit het dan ook aanleiding gegee tot interessante en innoverende navorsing (waarop later teruggekom word).

Navorsing oor die verskynsel dat sielkundige toetsprestasies van verskillende rassegroepe betekenisvol verskil, het oor die jare heen twee moontlike (en teen hierdie tyd alombekende) verklaringsoriëntasies aan die hand gedoen.

\section{Die oorerflikheidsbenadering}

Hierdie bepaalde standpunt naamlik dat verskille in toetsprestasie oorwegend verklaar kan word aan die hand van oorerflikheidsfaktore word gesteun deur navorsing van die vroegste dekades van die eeu.

Skattings van die persentasie wat oorerflikheidsfaktore bydra tot die verskil in gemete intelligensie is al deur die volgende navorsers gedoen: 


$\begin{array}{lcc}\text { Navorser } & & \frac{\text { \% Bydrae }}{66 \%} \\ \text { Burks } & (1928) & 66 \% \\ \text { Leahy } & (1935) & 78 \% \\ \quad \text { Newman, Freeman \& } & & \\ \quad \text { Holzinger } & (1937) & 65-80 \% \\ \text { Woodworth } & (1941) & 60 \% \\ \text { Burt } & (1958) & 77-88 \% \\ \text { Jensen } & (1969) & 80 \% \\ \text { Jencks et al. } & (1972) & 45 \%\end{array}$

Hoewel daar meningsverskil bestaan oor die formules wat gebruik word om die skattings te maak en oor die sinvolheid om 'n indeks van oorerflikheid vir eienskappe soos intelligensie te bereken, meen vermaarde skrywers soos Jensen (1969), Herrnstein (1973) en Eysenck (1975) dat sodanige skattings geldige aanduiders is van die bydrae wat oorerflikheidsfaktore tot intelligensie maak.

Navorsing wat daarop gemik is om die bydrae van genetiese faktore te bepaal neem gewoonlik biologiese verwantskap as onafhanklike veranderlike en probeer sover moontlik om vreemde veranderlikes konstant te hou of om daarvoor te korrigeer.

Erlenmeyer-Kimling en Jarvik (1963) vat die resultate van 52 van die bes ontwerpte studies wat oor 50 jaar uitgevoer is, en wat in hierdie kategorie val, in Figuur 2 saam.

Soos uit die figuur afgelei kan word, varieer intelligensietoetstellings van pare individue in ooreenstemming met die graad van hul biologiese verwantskap. Hoe meer individue geneties ooreenstem, hoe meer stem hul I.K.-tellings ooreen.

Hierdie resultate steun ooglopend die oorerflikheidstandpunt dog dit moet in gedagte gehou word dat namate individue biologies meer ooreenstem verskil die omgewings waarin hul opgroei normaalweg minder.

Studies wat uitgevoer is ná die verskyning van die werk van Erlenmeyer-Kimling en Jarvik en wat biologiese verwantskap as onafhanklike veranderlike implimenteer, steun in breë trekke die oorerflikheidstandpunt.

\section{Die omgewingsbenadering}

Volgens navorsers wat hierdie standpunt huldig moet die verskil in intelligensietoetsresultate tussen bevolkingsgroepe eerder aan 'n verskil in sosio-ekonomiese status toegeskryf word as aan genetiese faktore. 
Dat sosio-ekonomiese status verband hou met intelligensietoetstellings ('n korrelasie van tussen 0,25 en 0,50 word gewoonlik in die literatuur gerapporteer) is reeds voldoende bewys (Anastasi, 1965 en Tyler, 1965, pp. 331-364) en min wetenskaplikes betwyfel dit (Jensen, 1969, p. 75).

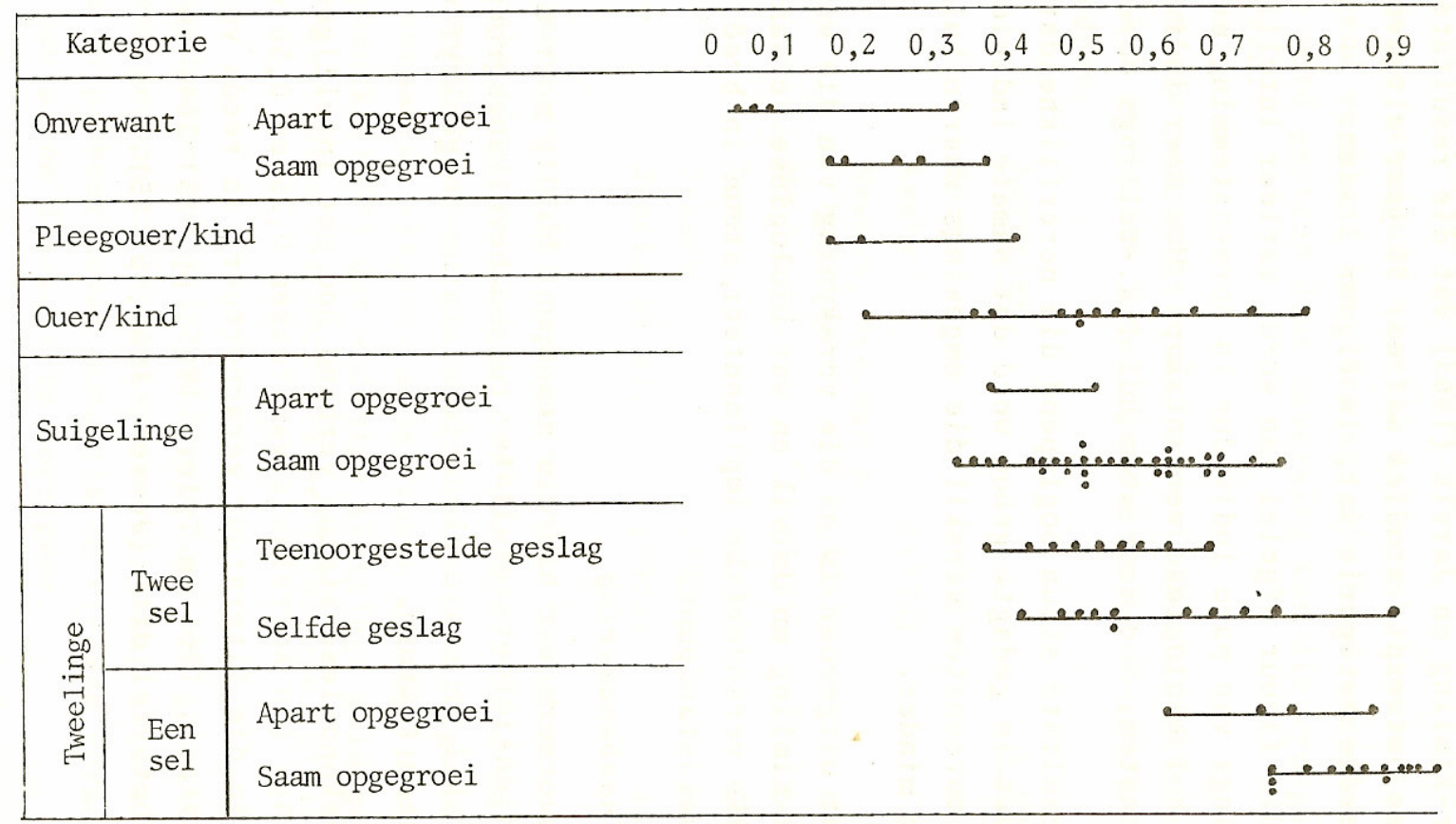

Figuur 2 : Korrelasies tussen I.K.'s van individue met geen tot volledige genetiese verwantskap

Loehlin et al. (1975) rapporteer 'n gemiddelde korrelasie van 0,30 vir Swartes en Nichols (1970) rapporteer 'n gemiddelde korrelasie van 0,33 vir Blankes.

Volgens die omgewingsbenadering neig omgewingsdeprivasie om in die laer sosioekonomiese of laer sosiale statusgroepe voor te kom en dit word gekenmerk deur 'n lae vlak van aspirasie en ongedifferensieërde en ongeartikuleerde verstandsfunksionering onder andere as gevolg van 'n onstabiele gesinslewe en 'n gebrek aan intellektuele stimuli, en dus die geleentheid om psigologies en intellektueel te groei - wat weer in intelligensietoetstellings gereflekteer word.

Die "Index of Status Characteristics" wat deur Warner en sy medewerkers ontwikkel is (Warner, Havighurst en Loeb, 1944) en dikwers deur navorsers op hierdie terrein gebruik word, neem die volgende faktore as basis vir die bepaling van sosiale status: beroep, inkomste, tipe huis en woongebied. Indien hierdie kriteria op verskillende bevolkingsgroepe 
van toepassing gemaak word, blyk dit dat Swartes in die VSA en ook hier te lande oorwegend in die laer sosiale statusgroepe val.

Die faktore wat dus in die laer sosiale statusgroepe tellings op intelligensietoetse teenwerk (as gevolg van kulturele armoede of deprivasie) sou dus ook die tellings van meeste Swartes nadelig beïnvloed - en vandaar dus die konstante verskil in intelligensietoetsprestasie tussen Blanke en Swart populasies.

\section{Omgewingsdeprivasie en Omgewingsverryking}

Hoewel daar geargumenteer kan word, oor die stelling dat omgewingsdeprivasie slegs die lot van sekere bevolkingsgroepe is, is daar heelwat navorsing gedoen en dus groter sekerheid oor die invloed van kulturele deprivasie op gemete verstandsfunksionering. Onderskeid moet hier gemaak word tussen kulturele deprivasie (waar daar feitlik geen sensoriese en motoriese stimulering aanwesig is nie) en kulturele verarming (cultural disadvantage). Laasgenoemde is van toepassing op meeste studies (volgens Jensen, 1969, p. 61) wat oor hierdie onderwerp gaan. Die oorgrote meerderheid van kinders wat onderworpe is aan sogenaamde kulturele deprivasie in die V.S.A. kan as kultureel verarmd beskou word en nie kultureel gedepriveer nie. Dit is 'n belangrike onderskeid wat getref moet word met die oog op die vertolking van navorsingsresultate soos later sal blyk.

Die invloed van kulturele verarming op verstandsfunksionering word redelik bevredigend gedemonstreer deur die bekende studies oor die kanaalboot-kinders in Engeland (Gordon, 1923) en die kinders in die afgeleë bergwêreld van Kentucky en Tennessee (Ascher, 1935; Sherman en Key, 1932 en Wheeler, 1932). In beide gevalle is by die kinders ondergemiddelde I.K.'s gemeet; in verbale toetse was die prestasie oor die algemeen laer as in nieverbale toetse en I.K. 's het gedaal namate die kinders ouer geword het.

Die invloed van gesinsgrootte en geboortevolgorde as moontlike vorme van kulturele armoede word deur die studies van onderskeidelik Zajonc en Markus (1975) en Belmont en Marolla (1973) gedemonstreer. Zajonc en Markus (aangehaalde werk) bevind dat daar 'n negatiewe verband $(-0,25)$ tussen familiegrootte en I.K.-tellings is selfs al word die effek van sosiale status gekontroleer, en Belmont en Marolla bevind dat intelligensie daal namate individue laer op die geboortevolgorde lys kom. Die bevindinge van die twee studies word in die volgende figuur saamgevat: 


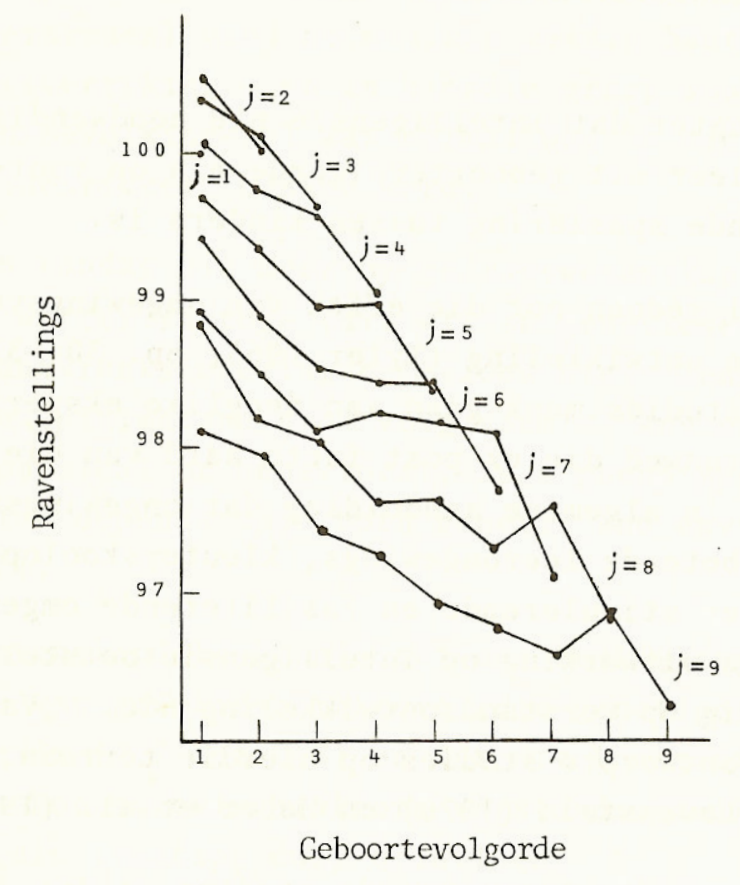

Figuur 3 : Gemiddelde getransformeerde Ravenstellings as 'n funksie van geboortevolgorde en gesinsgrootte $(j)$.

Die skrywers vertolk die resultate as 'n aanduiding van die toenemende ontbering deur kinders aan intellektuele stimulering deur hul ouers namate gesinne groter word. Die feit dat enigste kinders swakker vaar as eersgeborenes van gesinne met twee en drie kinders en dat laasgeborenes aansienlik swakker vaar as die res van die gesin, word daaraan toegeskryf dat diesulkes nie die geleentheid het om 'n onderrigrol in die gesin te vertolk nie. Die implikasie van hierdie bevindings vir verstandstoetsprestasie veral binne verskillende sosio-ekonomiese groepe, lê voor die hand.

Zajonc en Markus stel egter dat intelligensie nie noodwendig negatief hoef te korreleer met geboortevolgorde nie op voorwaarde dat daar voldoende spasiering tussen kinders is.

Heelwat navorsing is al gedoen oor die effek van omgewingsverryking op intellektuele ontwikkeling (Tyler 1965, pp. 306-323). Hoewel meeste van die studies mank gaan aan deeglike eksperimentele ontwerp (dikwels vanweë die ex post facto aard van die navorsingsopset) is daar ' $n$ algemene aanduiding dat omgewingsverryking by wyse van verbeterde leeromgewings, kleuterskoolopleiding, verhuising na meer stimulerende en fasiliterende omgewings en so meer 'n positiewe uitwerking op intelligensietoetstellings het, maar nie noodwendig op verstandsontwikkeling nie. Van die meer resente en beter ontwerpte studies op hierdie terrein, is dié van Skeels (1966) Levenstein (1970) en Heber et al. (1972). 
'n Belangrike kenmerk van die laasgenoemde studies is dat die kinders uit kultureel gedepriveerde (nie verarmde) omgewings kom, dat die kinders jonger as 2 jaar is en dat die ouers by die omgewingsverrykingsprogram betrek is. In programme waar dit nie die geval is nie was die algemene neiging dat gemete intelligensie aanvanklik toeneem maar dat dit na ongeveer twee jaar weer terugval na die oorspronklike vlak en later stelselmatig daal (Bronfenbrenner, 1975; Jensen, 1969). Jensen (1969, p. 60) praat van 'n omgewingsdrumpel in hierdie verband. Jong kinders wat daaronder val (dit wil sê die kultureelgedepriveerdes) kan aansienlik baatvind by 'n verbetering van hul kulturele omgewing - in gemete I.K.terme kan dit soveel as 30 of meer punte beteken. Kinders wat egter bokant die drumpel val (dit wil sê die kultureelverarmdes) vind normaalweg weinig baat by enige vorm van omgewingsverryking - en in hierdie groep sou die grootste gedeelte van 'n bevolking val wat normaalweg in die literatuur as "kultuurgedepriveer" beskou word.

Dit is vandag nie meer by gedragswetenskaplikes 'n brandende vraag watter faktore (dit wil sê genetiese- of omgewingsfaktore) verstandsfunksionering beïnvloed nie. Jensen (1969) vat die algemene opiniestand soos volg saam: "Any observable characteristic, physical or behavioral, is a phenotype, the very existence of which depends upon both genetic and environmental conditions" (p.42).

Die wetenskaplike kennis tot ons beskikking dui daarop dat die bydrae van genetiese faktore (die genotipe) 'n aansienlike proporsie is $(0,7$ tot 0,8$)$ en dat dit konstant is. Die vraag is eerder hoe omgewingsfaktore verstandsontwikkeling en -funksionering (die fenotipe dus) beïnvloed.

\section{Sielkundige toetsing in die openbare arena}

Daar heers vandag ' $n$ intense belangstelling in nie-wetenskaplike kringe in sielkundige toetsing.

Die feit dat oorerwingsfaktore verstandsfunksionering beïnvloed en die mate waarin dit geskied het weinig te make met die gemeenskap se belangstelling in sielkundige toetsing. Die feit egter dat oorerwingsfaktore nie die enkel bepalende faktor van verstandsfunksionering is nie, dit wil sê dat omgewingsfaktore ook 'n rol speel, raak die nie-wetenskapswêreld ten nouste om die eenvoudige rede dat omgewingsfaktore deur die gemeenskap gereguleer en so gestruktureer kan word dat verstandsfunksionering daardeur beïnvloed kan word. Dit plaas sielkundige toetsing binne die kaders van die politiek, die sosiale etiek en selfs die religie. 
Waarom verstandsmeting egter in die brandpunt van aandag is het grootliks daarmee te make dat verstandsfunksionering tans nog as die mees algemene maatstaf gebruik word wanneer besluite geneem word oor die toelating van individue tot opleidings- en beroepsinstansies.

Dit kan verwag word dat daar in die toekoms ook met dieselfde strengheid na ander vorme van sielkundige toetse, soos belangstellings- en persoonlikheidsmetings, gekyk sal word namate laasgenoemde in opvoedkundige en beroepsituasies gebruik word.

\section{Historiese aanloop}

Die intense belangstelling van die openbare mening in sielkundige toetsing is minder as twee dekades oud. In die beroepswêreld het dit in 1963 'n aanvang geneem met die hofsaak tussen ene Leon Myart en die Motorola Maatskappy in die VSA. Myart, 'n Neger, is 'n werk by die Motorola Maatskappy geweier op grond van 'n 5-minute intelligensietoets, hoewel hy vorige relevante werkservaring gehad het. Myart het die saak aanhangig gemaak by die Illinois Fair Employment Practices Commission (IFEPC) op grond daarvan dat daar rassediskriminasie teen horn gepleeg is. Die uitspraak van die verhoor was dat:

- $\quad$ Myart 'n werk aangebied moet word

- $\quad$ die bepaalde toets nie meer gebruik mag word nie en dat

- $\quad$ elke nuwe toets wat in die plek daarvan ontwikkel word die omgewingsfaktore in aanmerking moet neem wat bydra tot kulturele deprivasie.

Hoewel hierdie uitspraak later deur die Hooggeregshof van Illinois ter syde gestel is, was dit die begin van die gereg se betrokkenheid by indiensnemingspraktyke in die VSA. Dit was ook die begin van ' $n$ hernieude belangstelling onder veral bedryfsielkundiges en psigometrici in toetsdiskriminasie en van die opstel van riglyne en wetgewing in die verband deur professionele verenigings soos die American Psychological Association (APA) en ook die Amerikaanse regering.

Die volgende figuur dui die belangrikste historiese "mylpale" in hierdie verband in kronologiese volgorde aan.

Die studies van Lopez (1966) Kirkpatrick et al. (1968) en Bartlett en O'Leary (1969) was belangrik in dié sin dat hul daarop gedui het dat toetsdiskriminasie wel bestaan en dat dit redelik algemeen voorkom. Die 1970 toetsriglyne van die Equal Employment Opportunity 
Commission het geweldig hoë standaarde gestel ten opsigte van die getuienis wat verlang word om aan te dui dat 'n toets geldig is (Glaser, 1975).

Nadat die Amerikaanse howe die riglyne begin toepas het, het die onhoudbaarheid daarvan dikwels in hofsake begin voorkom. Op aandrang van die Division for Industrial and Organizational Psychology van die APA en van die Equal Employment Opportunity Commision Council (wat die Civil Rights Act van 1966 moes implimenteer) is die riglyne hersien en is daar in 1978 "uniforme" riglyne geformuleer nadat alle belanghebbende instansies 'n bydrae gelewer het.

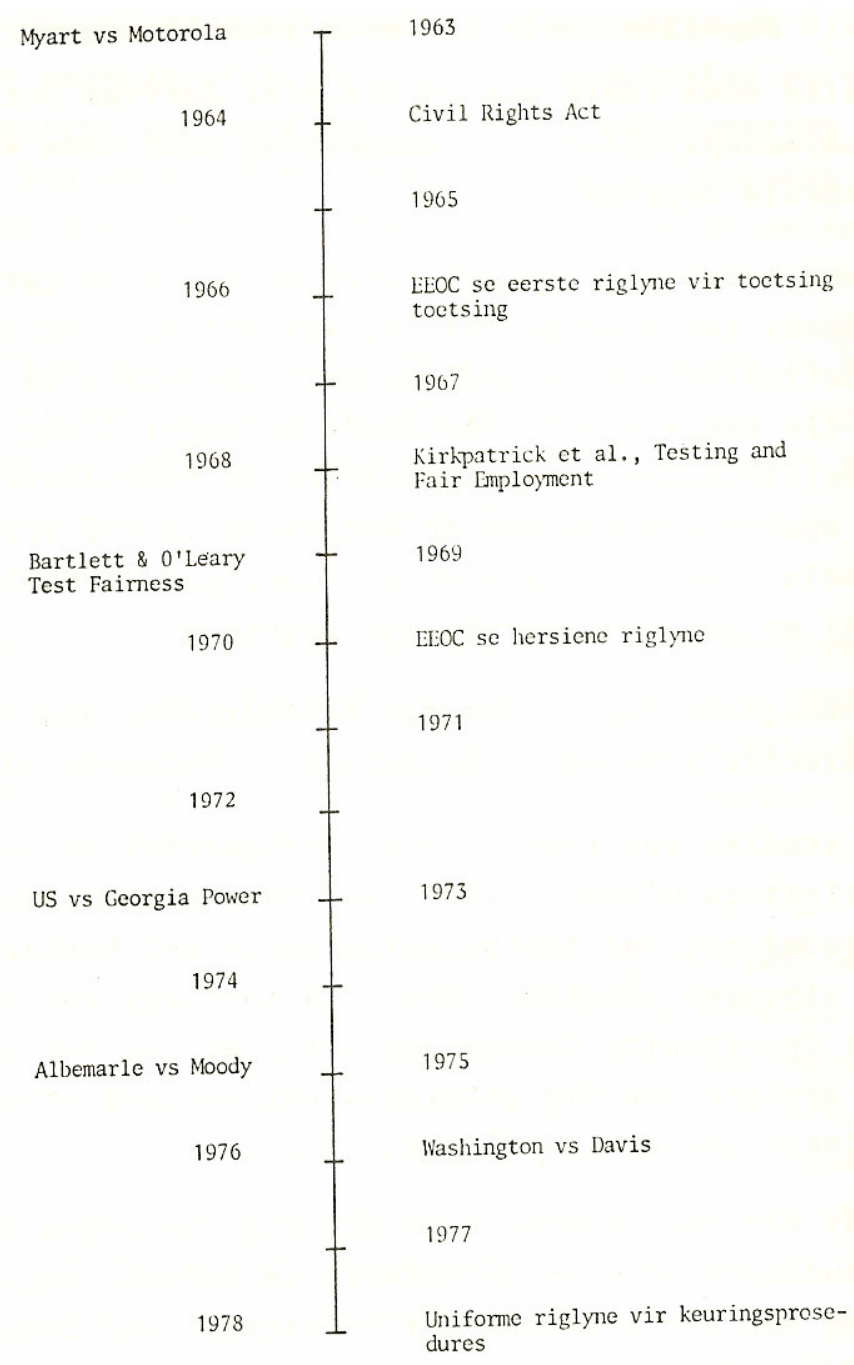

Figur 4 : Belangrikste gebeure met betrekking tot toetsdiskriminasie in die VSA 
Behalwe die genoemde riglyne is daar twee dokumente, een deur die APA in 1966 en een deur die Division for Industrial and Organizational Psychology van die APA in 1975 opgestel wat sekere standaarde lys waaraan toetse moet voldoen.

Die voorafgaande historiese oorsig dui daarop dat toetsgebruik in die beroepswêreld in die VSA met groot sorg bejeen word en dat bedryfsielkundiges veral nie onbetrokke kan wees by die uitdagings wat die praktyk stel nie.

\section{Nuwe benaderings tot die probleem}

Uit hierdie agtergrond van argument en teenargument rondom toetsdiskriminasie het interessante ontwikkelings na vore gekom. Eerstens het daar 'n nuwe belangstelling by navorsers ontstaan in 'n fyner omlyning van die omgewingsfaktore wat toetsprestasie beïnvloed en tweedens het nuwe toets- en keuringstrategieë die lig gesien.

\section{- $\quad$ Faktore wat toetsprestasie beïnloed}

\section{Voeding}

Hoewel heelwat navorsing en opnames in die VSA gedoen is oor ondervoeding as maatskaplike probleem is getuienis oor die verband wat dit met verstandsontwikkeling hou, skraal. Die slotsom waartoe Gussow (1974, p. 30) na 'n deeglike ondersoek op hierdie terrein kom is dat indien ondervoeding verstandelike vertraagdheid veroorsaak, dan moet dit vroeg (voor 2 jaar) in 'n ernstige graad, en langdurig voorkom. Jensen $(1969$, p. 73) kom tot dieselfde gevolgtrekking op grond van dié redenasie dat die brein in die eerste jaar aansienlike hoeveelhede proteïne nodig het. In die meeste ander werke op hierdie terrein word "logiese" beredenerings aangebied oor die moontlike invloed van ondervoeding en wanvoeding op toetsprestasie en dit kan derhalwe op hierdie stadium nog net as hipoteses vir toekomstige navorsing dien.

\section{Ontwikkeling van die selfbeeld}

Skrywers wys daarop dat selfbeeld nie aangebore is nie maar dat dit van die heel vroegste jare af ontwikkel en dat die omgewing waarin die kind opgroei 'n besondere invloed op selfbeeldontwikkeling het. Selfbeeld word gevorm en geslyp deur 'n voortdurende proses van interaksie wat die individu met sy omgewing het. Navorsers kom in hierdie verband tot die gevolgtrekking dat die gesins- en omgewingstoestande van minderheidsgroepe in die VSA 
van so 'n powere gehalte is (Prohansky en Newton, 1968) dat die selfbeeldontwikkeling van kinders in daardie huisgesinne besonder nadelig beïnvloed word (Clark en Clark, 1950, pp. 341-350). Hieruit word dan die afleiding gemaak dat prestasie op skool en dan veral in intellektuele toetse nadelig deur 'n negatiewe selfbeeld beïnvloed word.

\section{Motivering}

Die invloed wat motivering op prestasie het, is reeds goed gedokumenteer (McClelland, 1964). Dit blyk uit navorsing dat studente van laer sosiale-statusgroepe oorwegend swakker gemotiveer is as die uit hoër statusgroepe (Lowell, 1952 en Rosen, 1959) en dat die prestasiemotief by middelklas Blanke kinders teen skoolgaande ouderdom goed geïnternaliseer is (Katz, 1968). Motivering word egter in die huis gekultiveer en in hierdie opsig speel die ouer deur instruksie en voorbeeld 'n vername rol (Rosen, 1959).

Angs

Heelwat navorsing is al gedoen oor angs en toetsprestasie by skoolkinders en studente (Waite et al., 1958 en Castenada, McCandles en Palermo, 1956). Die bevindings is meesal dieselfde. Kinders met lae angs presteer beter as die met hoë angs. Angs word verhoog deur faktore soos vrees vir mislukkings en straf, swak selfbeeld en minderwaardigheidsgevoelens, negatiewe ervarings met skooleksamens en toetse, onbekendheid met toetssituasie en prosedure, en so meer. Hawkes en Furst (1971) bevind dat aangesien hierdie faktore meer aanwesig is by minderheidsgroepe, laasgenoemde meer geneig is tot hoër angs. Feldhausen en Klausmeier (1962) bevind ook dat kinders met lae I.K.-tellings meer angs ervaar as kinders met besondere hoë I.K. 's vir wie die toetssituasie gewoonlik stimulerend werk.

Toetsomgewing

Hernieude belangstelling het gekom in die effek wat die toetsomgewing op toetsprestasie het. So het die College Entrance Examination Board (CEEB) in die V.S.A. die Committee on Hostile Test Center Environment in 1971 in die lewe geroep om ondersoek in te stel na toetsomgewingsaspekte van die CEEB se toetsdiens wat 'n negatiewe invloed op die toetsprestasie van veral minderheidsgroepe kon hê. Weliswaar is hier dan ook heelwat knelpunre aangedui.

Navorsingstudies oor die effek van toetsomgewingstoestande op toetsprestasie is by hernuwing nagelees en het as stimulus en agtergrond begin dien vir verdere navorsing op 
hierdie terrein. In hierdie verband rapporteer Jensen (1969, p. 100) byvoorbeeld 'n toename van tussen 8 en 10 I.K.-punte nadat kinders uit kultureelverarmende gemeenskappe eers vertroud gemaak is met die toetsomgewing en Rosenthal en Hacobson (1968) bevind dat die verwagtings van onderwysers ' $n$ betekenisvolle invloed het op toets- en skoolprestasie veral in die eerste skooljare.

Taal

Van al die faktore wat toetsprestasie nadelig kan beïnvloed wil dit voorkom asof gebrekkige taalontwikkeling die grootste struikelblok kan wees vanweë die feit dat daar in meeste intelligensietoetse sterk gesteun word op verbale vermoëns. Dat taalbeheer sterk verband hou met prestasie op intelligensietoetse, is deur heelwat navorsing gedemonstreer (onder andere Klineberg, 1935 en Anastasi en Cordova, 1953). Ook die verband wat taalontwikkeling met sosiale status het, is oortuigend in navorsing gedemonstreer. Bereiter et al. (1966) kom onder andere tot die gevolgtrekking dat kultureel verarmde gemeenskappe in die VSA nie alleen 'n onderontwikkelde vorm van standaard Engels praat nie, maar dat dit 'n nie-logiese vorm van ekspressiewe gedrag is.

\section{- $\quad$ Onkonvensionele toetsstrategieë}

Kultuurvrye en kultuurbillike toetse

Met kultuurvrye toetse is die uitgangspunt dat indien alle kulturele faktore konstant gehou word, daar geen verskil behoort te wees tussen die gemiddelde intellektuele vermoë van individue met verskillende sosio-ekonomiese agtergrond nie.

Met kultuurbillike toetse word van die standpunt uitgegaan dat oorerwing- en omgewingsfaktore in alle stadiums van ontwikkeling van die individu met mekaar interreageer. Om kultuurverskille dus uit die situasie te hou, word slegs daardie kennis, ervaring en vaardighede in toetse ingebou wat gemeenskaplik (dit wil sê ewe bekend of ewe onbekend) aan alle kulture is. Volgens hierdie strategie word nie alleen streng gekyk na verbale inhoud nie maar ook na items met kennis-, vaardigheids-, en ervaringsinhoud. Spoed figureer normaalweg nie in kultuurbillike toetse nie.

Dit word vandag algemeen deur sielkundiges aanvaar dat die kultuurvry en kultuurbillike toetsbenadering nie besonder suksesvol was nie. In baie gevalle het individue 
uit minderheidsgroepe net so swak indien nie swakker nie, gevaar as in gewone toetse. Tannenbaum (1965, pp. 722-723) stel dit dat deur groepsverskille op hierdie manier te versluier nie beteken dat toetssydigheid uitgeskakel word nie. Dit beperk slegs die soort van inligting wat ingewin kan word oor swakpunte en sterkpunte in probleemoplossing. So 'n toets kan nie as ' $n$ intelligensietoets beskou word nie en dit gee ook geen informasie oor die invloed wat kultuur op toetsprestasie het nie.

\section{Kultuurspesifieke benadering}

Die grondliggende gedagte by hierdie benadering is om ' $\mathrm{n}$ toets en norms vir alle kultuurgroepe op te stel. In die Amerikaanse konteks het hierdie benadering nie veel lewenskrag getoon nie vanweë die koste daaraan verbonde, die probleem om die grense van 'n kultuurgroep akkuraat te trek en die beperkte bruikbaarheid van die resultate wanneer dit buite die bepaalde kultuur- groep, dit wil sê in die breë Amerikaanse samelewing, aangewend moet word.

In 'n poging om sommige van hierdie probleme te omseil het Mercer (in Samuda, 1975) die volgende benadering gevolg. 'n Gewone verstandstoets soos die WISC word geadministreer en die ouers van die kinders voltooi 'n vraelys om vas te stel in watter sosiokulturele groep van 'n bepaalde etniese groep die kind val. Die I.K. van die kind word dan geïnterpreteer teen die norms vir die bepaalde sosio-ekonomiese groep waarin hy/sy ressorteer.

Die benadering is dus dat daar nie norms vir etniese groepe opgestel word nie, maar vir sosio-kulturele groepe binne etniese groepe.

\section{Omgewingsmeting}

Hoewel daar baie meetmiddels is om eienskappe van die individu te meet, is daar min om die kenmerke van die omgewing te meet waarin die individu opgroei en ontwikkel. Indekse van sosiale status is nuttig maar dit verstrek min inligting oor die spesifieke wyses waarop omgewingsfaktore die ontwikkeling van sekere gedragseienskappe beïnvloed.

In 'n poging om hierdie leemte aan te vul het Wolf (1964) 'n skedule ontwikkel waarvolgens 13 eienskappe van die omgewing "gemeet" kan word. Dit dek die volgende hoofareas: Prestasiemotivering, Taalontwikkeling en Algemene leerervaringe. Wolf bevind 
dan ook in sy navorsing dat hierdie benadering tot die meting van die omgewing tot drie keer meer van die variansie in algemene intelligensie verklaar as 'n indeks van sosiale status.

Dit kan dus, volgens Wolf besonder goed saam met intelligensiemeting aangewend word om akademiese sukses van minderheidsgroepe te voorspel en om leemtes in hul opleidingservaring te identifiseer.

\section{Kriteriumgeankerde toetsing}

Die kontroversie oor toetsing en veral die wyse waarop dit in die Amerikaanse onderwys en beroepsituasie gebruik word, het aanleiding gegee tot interessante nuwe verwikkelings op hierdie terrein. Van die meer beproefde benaderings is geïndividualiseerde opleiding, bemeesteringsleer (learning for mastery), hiërargiese stapeling van opleiding, rekenaarondersteunde opleiding, geprogrammeerde opleiding en so meer.

Kriteriumgeankerde toetsing het teen hierdie agtergrond ontwikkel. Kriteriumgeankerde toetsing verskil van normgeankerde toetsing daarin dat tellings in ' $n$ kriteriumgeankerde toets nie vergelyk word met enige verwysingsgroep of normgroep nie. 'n Individu se toetstelling kry slegs betekenis in die lig van voorafbepaalde standaarde van prestasie. Die belangrikste indeks hier is die verskil tussen die individu se telling op die toets en die kriteriumtelling. Die verskil dui nie net 'n verskil in vlak aan nie, maar ook 'n verskil in vermoëns, kennis- en vaardigheidsprofiele. Sodoende kan opleidingsareas geïdentifiseer word waarin die individu tekort skiet.

Toetsing met betrekking tot verskillende vorms van leer

Op grond van 'n langtermyn navorsingsprogram kom Jensen (1969, pp. 107-117) tot die gevolgtrekking dat daar 'n onderskeid gemaak moet word tussen minstens twee vorme van leervermoë wat albei in die opvoedingswêreld en die beroepswêreld van belang is, naamlik assosiatiewe leer en konseptuele of kognitiewe leer. Assosiatiewe leer vereis min inligtingstransformasie tussen stimulus en respons terwyl kognitiewe leer self-geïnisieerde uitbreiding en transformasie van inligting vereis.

Hy bevind dat assosiatiewe leer normaal versprei is oor sosio-ekonomiese groepe heen, maar dat daar 'n sosio-ekonomiesbepaalde verskil is in die verspreiding van die kognitiewe leervermoë soos in die volgende figuur aangedui: 


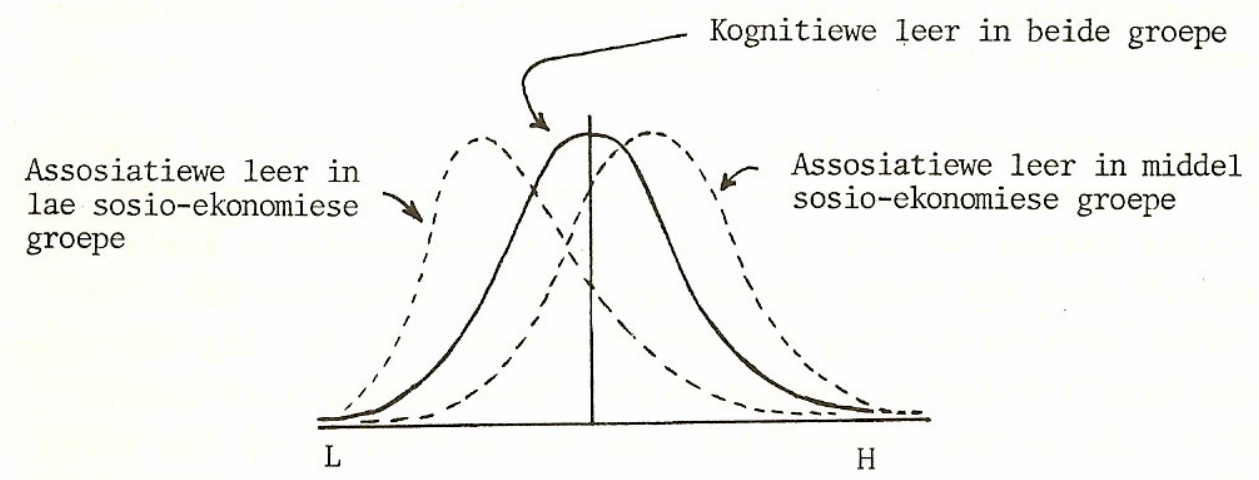

Figuur 5 : Verspreiding van verskillende vorme van leervermoë volgens sosio-ekonomiese groepe.

Assosiatiewe leer is 'n "voorvereiste" vir kognitiewe leer maar die teenoorgestelde geld nie. Menige leertake in die opvoedings- en beroepswêreld kan, volgens Jensen, as assosiatiewe leer geklassifiseer word en is as sodanig binne die bereik van laer sosioekonomiese groepe. Die tradisionele skoolstelsel lê grootliks klem op kognitiewe leer aangesien dit 'n middelklas gebaseerde stelsel is. Indien die bevindinge en redenasie van Jensen die navorsingstoets van die tyd kan weerstaan, hou dit aansienlike implikasies vir sielkundige toetsontwikkeling in.

\section{- $\quad$ Keuringstrategië}

Die hofsake, waarna vroeër verwys is, het hoofsaaklik gegaan oor diskriminerende keuringspraktyke in die Amerikaanse beroepswêreld.

Veral bedryfsielkundiges en psigometrici het daarop gereageer deur ' $n$ hele aantal keuringstrategieë te ontwikkel wat diskriminasie by keuring aan bande sou lê. Hoewel die strategieë oorwegend ontwikkel is vir indiensneming is die beginsels onderliggend daaraan relevant tot enige keuringsituasie - ook in die onderwyswêreld.

Die rigsnoer vir die ontwikkeling van verskeie keuringstrategieë die afgelope dekade was deurgaans, wat die navorser onder " $\mathrm{n}$ "billike keuringstrategie" verstaan. Aanvanklik is die konseptuele omlyning van billikheid in keuringsverband steeds verfyn (vergelyk Humphreys, 1973 en Boehm, 1972 byvoorbeeld). Later egter, het navorsing daarop gedui dat billikheid nie ' $n$ enkelvoudig-rasionele konsep is nie, maar dat die keuringsmodel wat uiteindelik gebruik word afhanklik is van wat die gebruiker se definisie van billikheid in 
keuringsverband is en laasgenoemde is weer gebaseer op etiese (en dus nie-rasionele) oorwegings (Hunter en Schmidt, 1976). Die jongste navorsing in hierdie verband (Ledvinka, Markos en Ladd, 1982) toon aan dat sekere langtermyn konsekwensies van die gebruik van bepaalde strategieë nie die verwagte voordele vir minderheidsgroepe inhou nie.

Differensiële geldigheid

Wanneer die verband tussen 'n toets en 'n kriterium vir verskillende subgroepe verskillend is, word soms aanvaar dat die toets nie in 'n gelyke mate diskrimineer nie. Dus, die toets is nie ewe geldig vir die verskillende subgroepe nie - soos in die volgende figuur aangedui:

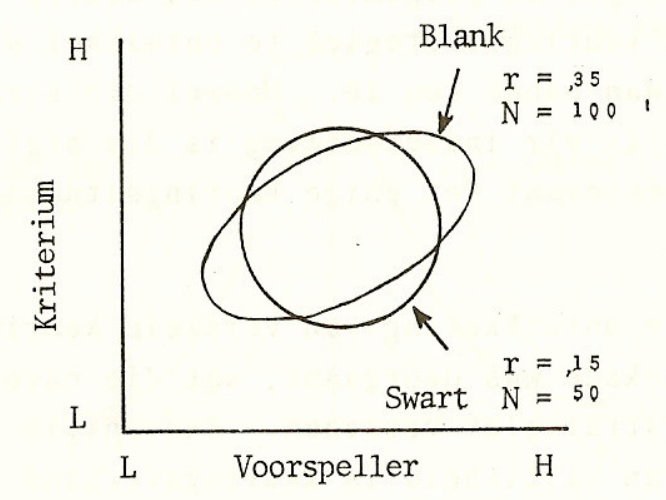

Figuur 6: Korrelasie tussen voorspeller- en kriteriumtellings vir Swart en Blanke groepe van verskillende grootte.

Hoewel die begrip differensiële geldigheid redelik eenvoudig is, was dit nie van die begin af duidelik hoe daar vir die beduidenheid daarvan getoets moet word nie. Aanvanklik is bepaal of elk van die koëffisiënte beduidend van nul verskil. Indien een beduidend sou verskil en die ander nie, is daar tot die gevolgtrekking gekom dat die toets nie in albei gevalle geldig is nie.

Humphreys (1973) is egter van oordeel dat sodanige resultaat nie genoegsaam aanduiding is dat differensiële geldigheid bestaan nie. Om te bepaal of twee korrelasiekoëffisiënte van mekaar verskil, moet hulle met mekaar vergelyk word. Die vraag is dus nie of $r_{1}$ of $r_{2}$ gelyk aan nul is nie, maar of $r$ vir een groep gelyk is aan $r$ vir ' $n$ tweede groep. In die voorbeeld in Figuur 6 is die toets geldig vir die Blanke groep en nie vir die Swart groep nie, terwyl die verskil tussen die twee korrelasies nie beduidend is nie. 
Boehm (1972, p. 33) meen die korrekter wyse om differensiële geldigheid te bepaal is om eers vas te stel of die twee korrelasiekoëffisiënte beduidend van mekaar verskil. Indien dit die geval is en minstens een van die koëffisiënte verskil beduidend van nul, dan het ons met differensiële geldigheid te doen. (In 'n uitgebreide ondersoek deur Schmidt, Berner en Hunter (1973) het dit aan die lig gekom dat differensiële geldigheid met betrekking tot Blanke vs. Swart groepe baie selde voorkom. Dit kan egter moontlik voorkom waar subgroepverdeling volgens geslag is (Schmidt, Mellon, en By Lenga, 1978)).

Verskil in regressielyne

Navorsers het gou besef dat toetsbillikheid meer behels as net differensiële geldigheid. Die verskille in gemiddelde prestasie op toetse en criteria moet in ag geneem word.

Die volgende figuur beeld die soort van diskriminasie uit wat in 'n keuringsituasie kan ontstaan:

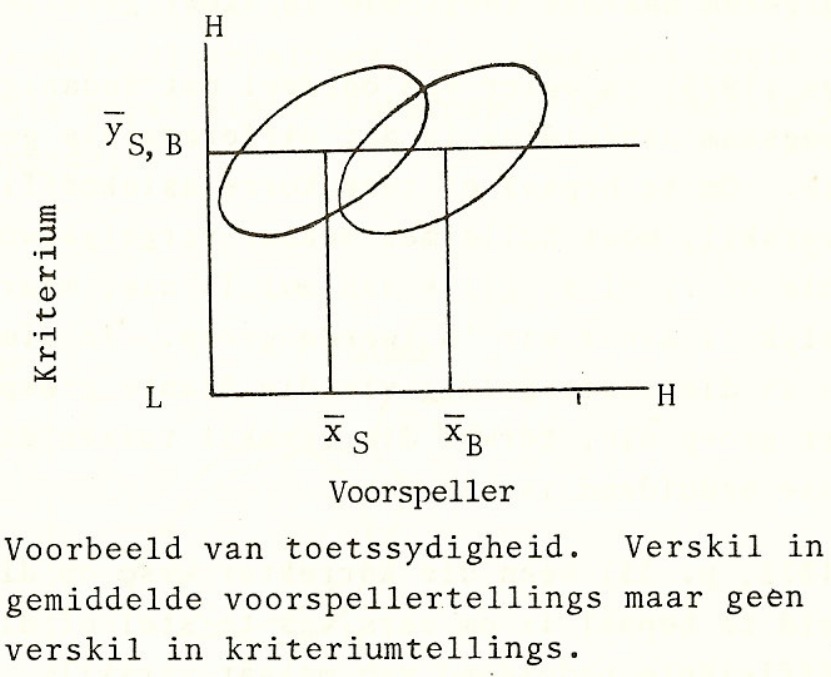

In die figuur is die geldigheidskoëffisiënt vir die Swart en Blanke groep dieselfde, die gemiddelde toetstellings verskil maar daar is geen verskil in prestasie op die kriterium nie. Dus, indien die gemiddelde toetstelling van die Blanke groep as afsnypunt gebruik word, sou geen Swarte in diens geneem gewees het nie terwyl die Blanke en die Swarte se kans op sukses in die werk gelyk was.

Dieselfde situasie kan uitgebeeld word met behulp van regressielyne soos in die volgende figuur : 


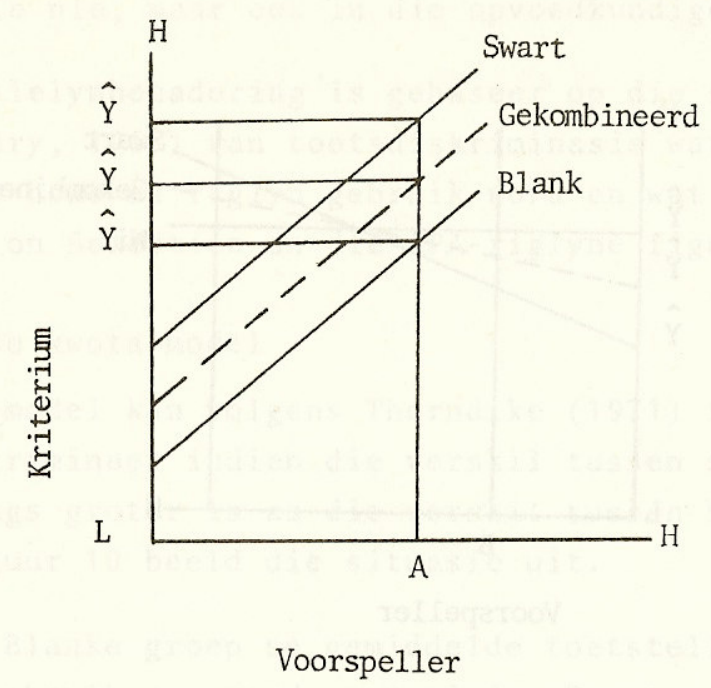

Figuur 8 : Regressielynuitbeelding van toetsdiskriminasie

Indien daar nie 'n aparte regressievergelyking vir elke groep uitgewerk word nie, dit wil sê indien slegs een vergelyking vir die totale groep gebruik word kan diskriminerende seleksie voorkom. Dieselfde toetstelling voorspel vir die Blanke groep 'n hoër kriteriumtelling en vir die Swart groep 'n laer kriteriumtelling as wat die geval sou gewees het indien aparte regressievergelykings gebruik is.

Indien die hellings van regressiekurwes vir verskillende groepe verskil en daar word slegs 'n gesamentlike vergelyking gebruik, kan onder- of oorvoorspelling van kriteriumtellings voorkom, afhangende van watter punt op die regressielyn ter sprake is.

Die geval word in figuur 9 uitgebeeld:

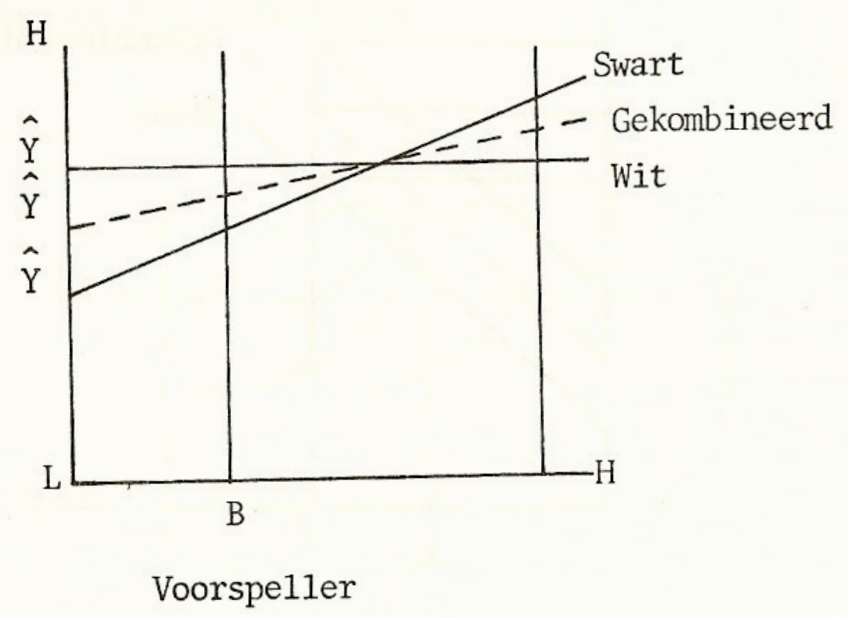

Figuur 9 : Regressielynuitbeelding van toetsdiskriminasie 
Billikheid kan dus bereik word indien 'n toets gebruik word waarvoor die regressielyn vir verskillende subgroepe dieselfde is, of indien die regressielyne verskil, deur elke subgroep se bepaalde regressievergelyking te gebruik. Die keuringstrategie sal dus wees om diegene met die hoogste voorspelde kriteriumtelling te kies.

(Beskikbare navorsing ten opsigte van regressielynhellings en afsnitte (byvoorbeeld Feild, Bayley en Bayley, 1977) dui daarop dat die hellings van regressiekurwes ten opsigte van Swart en Blanke groepe nie verskil nie maar wel die afsnitte. Afsnitte vir Swartes is deurgaans laer, dit wil sê kritriumtellings vir Swartes word oorvoorspel indien 'n gesamentlike regressielyn vir Swartes en Blankes gebruik word - dit geld nie alleen in die beroepsituasie nie, maar ook in die opvoedkundige situasie).

Die regressielynbenadering is gebaseer op die sogenaamde Cleary model (Cleary, 1968) van toetsdiskriminasie wat oorwegend deur Amerikaanse howe as riglyn gebruik word en wat in die Uniform Guidelines on Selection en die APA-riglyne figureer.

\section{Thorndike se kwota-model}

Die Cleary-model kan volgens Thorndike (1971) teen minderheidsgroepe diskrimineer indien die verskil tussen die twee groepe se toetstellings groter is as die verskil tussen hul kriteriumtellings. Figuur 10 beeld die situasie uit.

Indien die Blanke groep se gemiddelde toetstelling as keuringsafsnypunt gebruik sou word, sou minder Swartes geselekteer word as wat in werklikheid die werk suksesvol sou kon doen. Die afsnypunte vir die Swartes en Blankes moet derhalwe só gekies word dat die proporsie uit elke groep wat geselekteer word gelyk sal wees aan die proporsie van elke groep wat die werk suksesvol sal kan uitvoer.

Die voorafgaande is slegs enkele modelle van toetsdiskriminasie. Petersen en Novick (1976) en Hunter en Schmidt (1976) gee 'n breedvoerige uiteensetting van al die modelle wat op hierdie terrein ontwikkel is en die nadele en voordele aan elk verbonde. 
Afgesien van die verskillende benaderings wat gevolg kan word om toetsbillikheid te laat geskied, het die toetsontwikkelaar en toetsgebruiker met ' $n$ aantal meer fundamentele probleme te kampe.
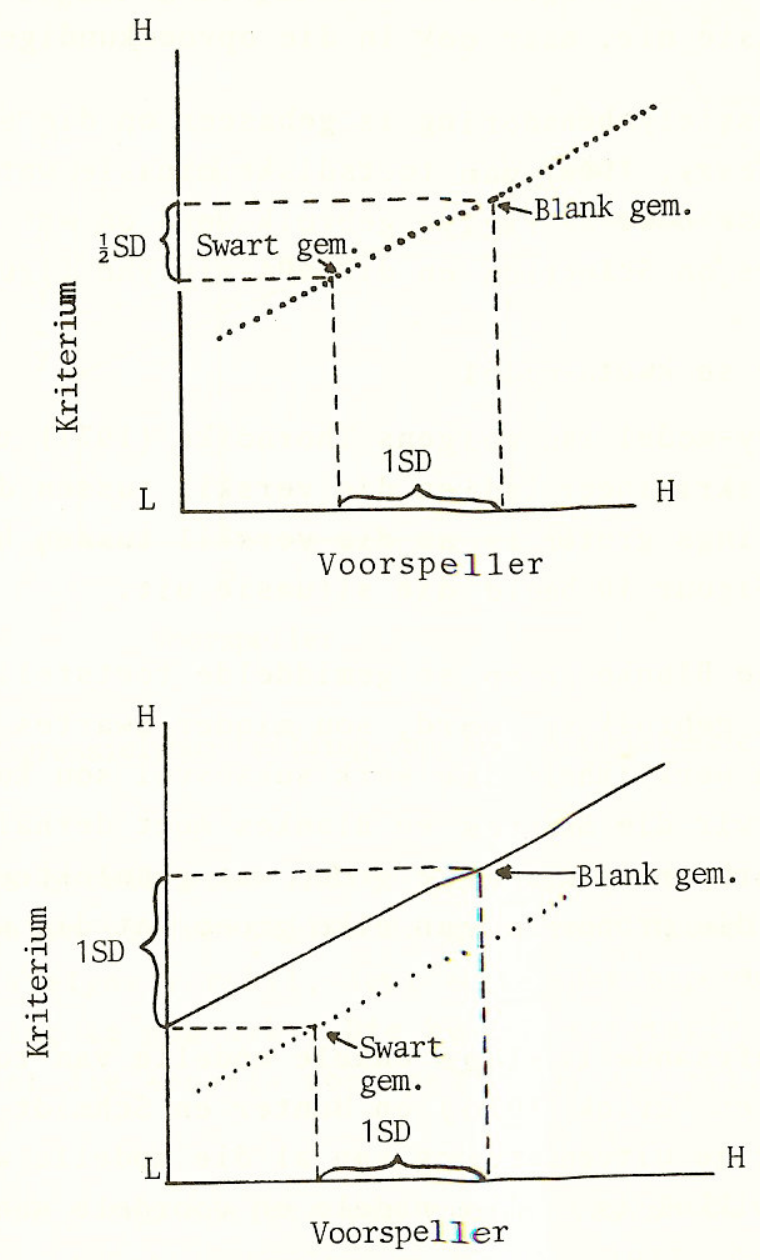

Figuur 10 : Ongelyke en gelyke verskille in voorspelleren kriteriumtellings

Die kriteriumprobleem

In situasies waar daar van sogenaamde sagte kriteriumgegewens gebruik gemaak word bestaan die moontlikheid dat al die verskillende vorms van beoordelingsfoute en dus ook diskriminasie kan insluip. Indien van sogenaamde harde kriteria gebruik gemaak word, word subjektiewe oordeel in 'n groot mate uitgeskakel maar dan bly staan die vraag of die maatstawwe van sukses wat gebruik word deurgaans relevant is - ook in die opvoeding- en onderwyssituasie. 


\section{Monstergroottes}

In die beroepsituasie waar die geldigheid van elke keuringstoets wat gebruik word bepaal behoort te word, is klein monsters dikwels 'n groot probleem. Vir die volgende redes :

- $\quad$ 'n korrelasiekoëffisiënte bereken op 'n klein 'monster moet hoër wees om beduidend te wees as vir 'n groot monster

- $\quad$ 'n korrelasiekoëffisiënte bereken op 'n klein monster is minder betroubaar as 'n koëffisiënte wat op groter monsters bereken is. Dit wil sê die standaardfout van die korrelasiekoëffisiënte is relatief groter vir kleiner monsters .

- $\quad$ Die waarskynlikheid om 'n toets geldig te bewys wat in werklikheid geldig is, is laer vir kleiner monsters as vir groter monsters.

Resente navorsing (Schmidt, Hunter en Urry, 1976) toon aan dat gevestigde gebruiksreëls so ver dit monstergroottes aangaan, dikwels ontoereikend is.

Veralgemeende geldigheid

Veralgemening van toetsgeldigheid van een werk na 'n ander is vir baie jare met skeptisisme deur bedryfsielkundiges bejeën met dié veronderstelling dat geen twee werke presies dieselfde is nie. Jongere navorsing toon dat sodanige argument nie noodwendig altyd water hou nie (Schmidt en Hunter, 1977 en Arvey en Mossholder, 1977).

Die Uniforme riglyne en die Amerikaanse howe staan egter nie onwrikbaar op die eis van 'n aparte geldigheidstudie vir elke werk nie. Wanneer 'n wetenskaplike werksontleding toon dat twee werke wat die hooffunksies daarvan betref, ekwivalent is, word veralgemeende geldigheid in beginsel aanvaar. Dit demonstreer terloops die belang van die daarstelling en verbetering van werkontledingstelsels.

Inhoudsgeldigheid

Alhoewel inhoudsgeldigheid aanvanklik nie in toetsdiskriminasiesake ter sprake was nie, het meer resente Amerikaanse hofuitsprake daarop gedui dat inhoudsgeldigheid as 'n aanvaarbare valideringstrategie aanvaar word.

Dit blyk ook dat organisasies sowel as applikante die strategie aanvaar omdat dit al die psigometriese ingewikkeldhede van onbillike toetsdiskriminasie omseil en omdat dit die kennis, vaardighede en gedrag wat in 'n bepaalde situasie ter sake is, direk aanspreek. 


\section{AFSONDERLIKE OF GESAMENTLIKE TOETSE VIR VERSKILLENDE}

\section{BEVOLKINGSGROEPE}

Die inligting in die voorafgaande gedeeltes is maar 'n klein fraksie van kennis wat op hierdie terrein van toepassing is en oor heelwat aspekte is daar ook nog nie voldoende wetenskaplike antwoorde nie. Dit op sigself vra om nog heelwat sinvolle en probleemgerigte navorsing. By dit alles is daar ook sosiaal-maatskaplike oorwegings wat naas die wetenskaplike feite, in oorweging geneem moet word. Om dus 'n klinkklare antwoord op bostaande vraag te gee, is feitlik 'n onmoontlike taak.

Die tyd en omstandighede vereis egter besluite in die verband en dit sou dwaas wees om bestaande wetenskaplike kennis te liasseer totdat alle moontlike inligting ingewin is. Die korrekste optrede vir die toetsmaker sou dus wees om sy besluit streng in die lig van die wetenskaplike kennis tot sy beskikking te neem. Op hierdie stadium lyk dit dus of dieselfde toets vir afsonderlike bevolkingsgroepe gebruik behoort te word en dat normberekening op grond van sosio-ekonomiese status behoort te geskied.

\section{VERWYSINGS}

Annastasi, A. Psychology; psychologists and psycho-analogical testing. American Psychologist, 1967, 22, 297-306.

Anastasi, A. Differential Psychology. New York: Macmillan, 1965.

Anastasi, A. \& Cordova, F.A. Some effects of bilingualism upon the intelligence test performance of Puerto Rican children in New York City. Journal of Educational Psychology, 1953, 44, 1-19.

Arvey, R.D. \& Mossholder, K.M. A proposed methodology for determining similarities and differences among jobs. Personnel Psychology, 1977, 30, 363-374.

Asher, E.J. The inadequacy of current intelligence tests for testing Kentucky mountain children. Journal of Genetic Psychology, 1935, 46, 480-486.

Bartlett, C.J. \& O'Leary, B.S. A differential prediction model to moderate the effects of heterogeneous groups in personnel selection and classification. Personnel Psychology, 1969, 22, 1-18.

Baughman, E.E. \& Dahlstrom, W.G. Negro and White children: A psychological study in the rural South. New York: Academic Press, 1968.

Belmont, L. \& Marolla, F.A. Birth order, family size and intelligence. Science, 1973, 182, 1096-1101.

Bereiter, C. et al. An academically orientated pre-school for culturally deprived children. In F.M. Hechinger (Ed.) Pre-school education today. New York: Doubleday, 1966.

Boehm, V.E. Negro-white differences in validity of employment and trainirg selection procedures: Summary of research evidence. Journal of Applied Psychology, 1972, 56, 33-39. 
Bronfenbrenner, U. Nature with nurture: A reinterpretation of the evidence. In A. Montagu (Ed.) Race and I.Q. New York: Oxford University Press, 1975.

Burks, B.S. The relative influence of nature and nurture upon mental development: A comparative study of foster parent-foster child resemblance. Yearbook of the National Society for the Study of Education, 1928, 27(1), 219-316.

Burt, C. The inheritance of mental ability. American Psychologist, 1958, 13, 1-15.

Castenada, A., McCandless, B.R. \& Palermo, D.S. The children's form of the Manifest Anxiety Scale. Child Development, 1956, 27, 317-326.

Cattell, R.B. Abilities: Their structure, growth and action. Boston: Haughton Mifflin, 1971.

Chissom, B.S. \& Lanier, D. Prediction of 1st quarter freshman GPA using SAT scores and high school grades. Educational and Psychological Measurement, 1975, 35, 461-463.

Clark, K.B. \& Clark, M.P. Emotional factors in racial identification and preference in Negro children. Journal of Negro Education, 1960, 19, 341-350.

Cleary, A.T. Test bias: Prediction of grades of Negro and White students in integrated colleges. Journal of Educational Measurement, 1968, 5, 115-124.

Ebel, R.L. The social consequences of educational testing. Proceedings of the 1963 International Conference on Testing Problems. Princeton, N.J. Educational Testing Service, 1963, 130-143.

Erlenmeyer-Kimling, L. \& Jarvik, L.F. Genetics and intelligence: A review. Science, 1963, $142,1477-1479$.

Eysenck, H.J. The inequality of man. San Diego: Edits, 1975.

Feldhusen, J.J. \& Klausmeyer, H.J. Anxiety, intelligence and achievement in children of low, average and high intelligence. Child Development, 1962, 33, 403-409.

Feild, H., Bailey, G.A. \& Bayley, S. Employment test validation for minority and nonminority production workers. Personnel Psychology, 1977, 30, 37-46.

Glazer, N. Affirmative discrimination: Ethnic inequality and public policy. New York: Basic Books, 1975.

Goldfarb, W. Variations in adolescent adjustment of institutionally reared children. Journal of Anthropsychiatry, 1947, 17, 449-457.

Gordon, H. Mental and scholastic tests among retarted children. London: Board of Education Pamphlet No. 44, 1923.

Goslin, D.A. Standardized ability tests and testing. Science, 1968, 159, 851-855.

Gussow, Joan D. Nutrition and mental development. ERIC/IRCD Urban Disadvantages Series, 1974, 36, 1-41.

Haggard, E.A. Social status and intelligences: An experimental study of certain cultural determinants of measured intelligence. Genetic Psychology Monographs, 1954, 49, 141-186.

Hawkes, T.H. \& Furst, N.F. Race, socio-economic situation, achievement, I.Q. and teacher ratings of student behavior as factors relating to anxiety in upper elimentary school children. Sociology of Education, 1971.

Heber, R., Garber, H. \& Herrington, S. Rehabilitation of families at risk for mental retardation. Progress report. December 1972, Rehabilitation Research and Training Center in Mental Retardation, University of Wisconsin, Macuson, Wisconsin.

Herrnstein, R.J. IQ in the meritocracy. Boston: Atlantic Monthly Press, 1973.

Humphreys, L.G. Statistical definitions of test validity for minority groups. Journal of Applied Psychology, 1973, 58(1), 1-4.

Hunter, J.E. \& Schmidt, F.L. Critical analysis of the statistical and ethical implications of various definitions of test bias. Psychological Bulletin, 1976, 83, 1053-1071. 
Jencks, C., Smith, M., Acland, H., Bone, M.J., Cohen, D., Cintis, H., Heynes, B. \& Michelson, S. Inequality: A reassessment of the effect of family and schooling in America. New York: Basic Books, 1972.

Jensen, A.R. How much can we boost IQ and scholastic achievement? Harvard Educational Review, 1969, 39, 1-123.

Katz, I. Academic motivation and equal educational opportunity. Harvard Educational Review, 1968, 38, 56-65.

Kirkpatrick, J.J., Ewen, R.B., Barnett, R.S. \& Ratzell, R.A. Testing and fair employment. New York: University Press, 1968.

Klineberg, O. Negro intelligence and selective migration. New York: Columbia University Press, 1935.

Lavin, D.E. The prediction of academic performance: A theoretical analysis and review of research. New York: Russel Sage Foundation, 1965.

Leahy, A.M. Nature-nurture and intelligence. Genetic Psychology Monographs, 1935, 17, 234-308.

Ledvinka, J., Markos, V.H. \& Ladd, R.T. Long-range impact of "fair selection" standards on minority employment. Journal of Applied Psychology, 1982, 67, 18-36.

Levenstein, P. Cognitive growth in preschoolers through verbal interaction with mothers. American Journal of Orthopsychiatry, 1970, 40, 426-432.

Loehlin, J.C., Lindzee, G. \& Spuhler, J. Race differences in intelligence. San Francisco: Freeman, 1975.

Lopez, F.M. Current problems in test performance of job applicants. Personnel Psychology, 1966, 19, 10-19.

Lowell, E.L. The effect of need for achievement on learning and performance. Journal of Psychology, 1952, 33, 31-40.

McClelland, D.C. The achieving society. New York: Van Nostrand, 1964.

Messick, S. \& Anderson, S. Educational testing, individual development and social responsibility. The Counselling Psychologist, 1970, 2, 80-88.

Newman, H.H., Freeman, F.N. \& Holzinger, K.J. Twins': A study of heredity and environment. Chicago: University of Chicago Press, 1937.

Nichols, P.L. The effects of heredity and environment on intelligence and test performance in 4 and 7 year white and Nego sibling pairs. Doktorale proefskrif, Universiteit van Minnesota. Ann Arbor, Michigan: University Microfilm. 1970, No. 71-18, 874.

Petersen, N.S. \& Novick, M.R. An evaluation of some models of culture-fair selection. Journal of Educational Measurement, 1976, 13, 3-29.

Prohansky, H. \& Newton, P. The nature and meaning of Negro self-identity. In M. Deutsch, I. Katz, \& A. Jensen. Social class, race and psychological development. New York: Holt, Rinehart \& Winston, 1968.

Rosen, B.C. Race, ethnicity, and true achievement syndrome. American Sociological Review, $1959,24,47-60$.

Rosenthal, R. \& Jacobson, L. Pigmalion in the classroom. Teachers' expectation and pubils: intellectual development. New York: Holt, Rinehart \& Winston, 1968.

Samuda, R.J. Psychological Testing of American Minorities Issues and consequences. New York: Harper \& Raw, 1975.

Schmidt, F.L., Berner, J.G. \& Hunter, J.E. Racial differences in validity of employment tests: Reality or illusion? Journal of Applied Psychology, 1973, 58, 5-9.

Schmidt, F.L., Hunter, J.E. \& Urry, V.W. Statistical power in criterion-related validation studies. Journal of Applied Psychology, 1976, 61, 473-485.

Schmidt, F.L. \& Hunter, J.E. Development of a general solution to the problem of validity generalization. Journal of Applied Psychology, 1977, 62, 529-540. 
Schmitt, N., Mellon, P.M. \& Bylenga, C. Sex differences in validity for academic and employment criteria and different types of predictions. Journal of Applied Psychology, 1978, 63, 145-150.

Sherman, M. \& Key, C.B. The intelligence of isolated mountain children. Child Development, 1923, 3, 279-290.

Shuey, A.M. The testing of Negro intelligence. New York: Social Science Press, 1966.

Skeels, H.M. Adult states of children with contrasting early life experiences. Monographs of the Society for Research in Child Development, 1966, 31(3, Reeks nr. 105).

Stanley, J.C. \& Porter, A.C. A correlation of Scholastic Aptitude Test scores with college grades for Negroes versus whites. Journal of Educational Measurement, 1967, 4, 199218.

Tannenbaum, A.J. Culture-fair intellignce test. In O. Buros. (Red.) Sixth mental measurement yearbook, test and reviews, 1965, 721-723.

Thorndike, R.L. Concepts of culture-fairness. Journal of Educational Measurement, 1971, 8, 63-70.

Tyler, L.E. The Psychology of human differences. New York: Appleton-Century-Crofts, 1965.

Waite, R.R., Sarason, S.B., Lighthall, F. \& Davidson, K. A study of anxiety and learning in children. Journal of Abnormal and Social Psychology. 1958, 57, 267-270.

Warner, W.L., Meeker, M. \& Eells, K. Social class in America. Chicago: Science Research Associates, 1949.

Warner, W.L., Havighrust, R.J. \& Loeb, M.B. Who shall be educated? New York: Harper \& Row, 1944.

Wheeler, L.R. The intelligence of East Tennessee children. Journal of Educational Psychology, 1932, 23, 351-370.

Wolf, R. The measurement of environments: Proceedings of the 1964 invitational conference on testing problems. New York: E.T.S., 1964.

Woodworth, R.S. Heredity and environment: A critical survey of recently published material on twins and foster children. New York: Social Science Research Bulletin. 1941, 47.

Zajonc, R.B. \& Markus, G.B. Birth order and intellectual development. Psychological Review, 1975, 82, 74-88. 